\title{
DAMPAK PERAN AYAH TERHADAP PERKEMBANGAN \\ EMOSIONAL ANAK USIA DINI
}

\author{
Tia Novela \\ tia_novela23@yahoo.com \\ PG-PAUD- FIP \\ UNIVERSITAS NEGERI PADANG
}

\begin{abstract}
ABSTRAK
Keluarga merupakan pendidikan yang didapatkan oleh anak usia dini dari orang tua anak mendapatkan nya. Didalam keuarga mempunyai pola asuh dari orang tua ayah dan ibu mempunyai peran penting yang sama. Orang tua akan menjadi contoh bagi anak sehingga apabila orang tua memberikan contoh yang baik dan positif dihadapan anak maka anak akan mencontoh perilaku yang baik dan positif tersebut. Peran orang ayah akan memberikan dampak terhadap anak. Pentingnya figure seorang ayah akan mempengaruhi perkembangank kognitif, sosial emosional pada anak. Karena dengan ada nya peran seorang ayah anak akan merasa senang, seorang ayah dapat memberikan motivasi kepada anak. Dengan mengetahui bagaimana peran ayah dan peran ibu maka anak akan rasa senang, emosi yang timbul terhadap anak pun emosi yang positif.
\end{abstract}

Kata kunci: Keluarga, Pola Asuh, Peran Ayah, Emosi

\begin{abstract}
Family is an education obtained by early childhood from parents of children get it. In the family have parenting from parents and mothers have the same important role. Parents will be an example for children so that if parents provide good and positive examples in front of children, children will imitate the good and positive behavior. The role of the father's person will have an impact on the child. The importance of a father's figure will affect the development of cognitive, social emotional in children. Because with the role of a father the child will feel happy, a father can provide motivation to the child. By knowing the role of the father and the role of the mother, the child will feel happy, the emotions that arise from the child are also positive emotions.
\end{abstract}

Keywords: Family, Parenting, Father's Role, Emotions 


\section{Pendahuluan}

Didalam suatu keluarga memiliki peran masing-masing didalam keluarga tersebut. Orang tua menjadi peran penting didalam keberlangsungan kehidupan keluarganya, seperti dampak peran ayah didalam keluarga. Untuk membesarkan dan merawat anak orang tua harus berkerjasama, bukan hanya tugas istri saja tetapi ayah juga mempunyai andail didalam membesarkan dan merawat anak tersebut. Didalam kehidupan berkeluarga merupakan tugas seorang ibu mengurus anak dan rumah dan sebaliknya tugas ayah untuk melengkapi kebutuhan ibu dan anak-anaknya dirumah. Sosok seorang ayah sangat di butuhkan oleh istri berserta anak-anaknya sehingga akan mempengaruhi perasaan dan sikap yang ditimbulkan istri kepada anak-anaknya.Peran ibu adalah Kaitan antara ibu dana anak mengakibatkan pengahuh yang besar dalam pembentukan sosial dan kepribadian anak untuk mempersiapkan masa yang akan dating (Dagun, 2002). Peran yang di miliki oleh ayah tidak kalah penting dari peran sorang ibu yang mengasuh dan mengurus anak dirumah sebab peran ayah juga penting dalam membentuk pertumbuhan dan perkembangan anak seperti perkembangn emosional pada anak.

Apabila seorang ayah memberikan kasih sayang sepenuhnya terhadap anak maka anak akan merasa senang dan merasa nyaman ketika dekat dengan ayahnya dan sebaiknya apabila seorang ayah tidak memberikan perhatian dan kasih saying kepada anak nya, maka anak akan merasa sedih dan merasa tidak nyaman ketika bersama ayahnya. Anak usia dini merupakan anak yang sangat membutuhkan sosok figure sorang ayah karna masing-masing dari ayah dan ibu mempunyai peran yang tidak dapat digantikan oleh siapapun. Peran ayah sangat harus paham dalam bagaimana tuntutan juga harus memahami suka duka kehidupan yang ada didalam keluarganya. Ayah dan ibu harus berkerja sama dalam mengasuh anak, oleh karena itu orang tua harus mempunyai pola asuh yang sejalan untuk mengasuh anak karena apabila pola asuh yang diberikan oleh orang tua terhadap anak berbeda maka akan mengakibatkan dampak terhadap emosi anak.

Anak usia dini merupakan dimana masa-masa emas atau disebut golden age. Pada masa ini lah pembentukan kognitif, , nilai agama moral dan sosial emosional. Sosok seorang ayah sangat penting mempengaruhi pembetukan emosional pada anak usia dini. 
Dengan memberikan sebuah kasih saying yang diberikan oleh seorang ayah kepada anaknya merupakan hal teladan yang baik dalam perilaku emosional maka anak pun akan menjadi makhluk individu yang baik pula. Sikap yang teladan merupakan perilaku yang positif yang diberikan oleh orang dewasa seperti orang tua seperti ayah kepada anak nya , dalam keluarga membantu mengembangkan potensi kemampuan emosi anak. Hal yang penting muncul pada usia dini adalah perkembangan emosional anak. Padahal suatu keharusan terhadap orang tua dalam menjalankan tugas sebagai orang tua (ayah dan ibu) dalam upaya pengembangan potensi anak secara maksimal, sehingga mereka dapat tumbuh dan berkembang sesuai dengan kemampuan masing-masing.

Pengembangan kemampuan dasar anak dalam berbagai bidang itu akan memberi pengaruh terhadap perkembangan anak untuk pendidikan selanjutnya terutama dengan prinsip pendidikan berkelanjutan sepanjang hayat. Sebagaimana diketahui dengan peran ayah dapat menjadi factor dalam mengembangkan kecerdasan emosi pada anak. Emosi perlu distimulasi sejak usia dini agar anak dapat tumbuh serta memiliki kecakapan emosi sesuai dengan tahap perkembangannya. seorang seharus nya memberikan sebuah motivasi terhadap anak nya karena motivasi adalah kemampuan untuk memberikan semangat kepada diri sendiri untuk melakukan sesuatu yang baik dan bermanfaat, anak usia dini membutuhkan halyang demikian dalam pembentukan emosinya. Perasaan marah, takut, senang, sedih, benci, cinta, antusias, bosan dan sebagainya adalah salah satu bentuk ekspresi dari emosi. Setiap orang pasti pernah mengalami emosi, namun cara mengatasi emosi pada setiap orang pastilah berbeda-beda. salah satu cara seorang ayah menegmbangkan emosi anak dengan cara bermain. Perkembangan emosi dapat melalui permainan karena bermain sangat penting dalam perkembangan emosi anak, melalu permainan anak dapat belajar mengendalikan emosi dan mengendalikan perhatiannya (Hazizah, 2018).

\section{Kajian Teori}

Keluarga

Keluarga merupakan suatu ikatan yang dibentuk oleh suatu perkawinan antara sepasang suami dan istri sehingga dapat menjalani kehidupan bersama, dengan tujuan yang sama 
dalam membina sebuah rumah tangga untuk mencapai keluarga yang sakinah dalam lindungan dan di rida Allah swt (Djamarah, 2014). Ketika menjalin kehidupan bersama secara sah menjadi suami dan istri, mereka harus hidup rukun dalam membentuk keluarga yang bahagia dan harmonis sehingga menciptakan kehidupan yang sejahtera lahir maupun bathin. Dalam keluarga mempunyai terdapat empat factor terpenting terhadap peran didalam rumah tangga yaitu pola, asuh, orang tua dan keluarga. Keluarga akan mejadi sebuah komunitas yang disebut komunitas satu atap. Pada dasarnya kehidupan bersama harus mempunyai kesadaran bahwa tinggal dilingkungan yang sama atau satu atap sebagai ayah dan ibu akan menjalin hubungan timbal balik dalam bersosialisasi.

\section{Pola Asuh Orangtua}

Didalam sebuah keluarga orang tua mempunyai atau harus dituntut keterampilan dalam manajemen( managerial skill) atau keterampilan teknis (technical skill). Sehingga didalam keluarag harus memiliki kiat dalam memikat hati anak, guna kemampuan membina keserasian antara anak dengan keahlian teknis membina anak, serta memberikan contoh yang tauladanterhadap anak sehingga anak bisa mencontoh bagaimana perilaku sehari-hari. Didalam keluarga terdapat lima macam pola asuh yang diberikan orang tua terhadap anaknya:

1. Pola asuh orang tua yang memberikan paksaan terhadap anaknya atau yang disebut otoriter. Pola asuh otoriter ini adalah Pola asuh ini diberikan orang tua terhadap anak dengan mengatur segala sesuatu mengenai. Disini orang tua tidak terbuka terhadap anak dan orang tua tidak memberikan kebeasan terhadap anak.

2. Pola asuh orang tua yang mengajak anak kerjasama didalam suatu hal disebut demokratis. Pola asuh demokratis adalah pola asuh yang memberikan kebebasan terhadap anak akan tetapi masih dibawah pengawasan atau kendali orangtua sehingga anak akan tau batasan-batasannya. Didalam pola asuh demokrasi ini memiliki karakteristik:

a. Makhluk yang paling termulia adalah manusia sehingga pada saat proses menjalankan pendidikan terhadap anak maka hal tersebut akan selalu menjadi titik tolak dalam proses pendidikan. 
b. Penyelarasan yang diberikan orang tua terhadap anak nya, sehingga orang tua akan selalu berusaha menyeimbangkan antara kepentingan anak dan tujuan pribadi.

c. Orang tua yang demokrasi ia akan membawa anak dalam posisi diskusi dimana adanya menerima saran dari anak, pendapat dari anak juda kritikan dari anak.

d. Memberikan pemahaman kepada anak, ketika anak melakukan kesalahan orang tua memberikan pendidikan pada anak agar jangan mengulangi kesalahan dengan memberikan alasan dan menggunakan komunikasi yang baik terhadap anak guna agar tidak menurunkan daya kreativitas, ide dan gagasan yang dikembangkan oleh anak.

e. Untuk mencapai suatu tujuan orangtua mengajak anak kerjasama.

3. Pola asuh yang diberikan orang tua kepada anak dengan membiarkn anak memonitoring aktivitas nya sendiri disebut permissif. Orang tua jarang menghukum anak ketika anak melakukan kesalahnnya sehingga anak diberikan kebebasan didalam setiap kegiatannya. Orang tua tidak mengontrol anak akan tetapi orangtua juga tidak menuntut anak. (Vivi, 2018)

Peran Ayah

Efek peran ayah terhadap anak usia dini sangatlah berpengaruh untuk jangka panjang karena seorang ayah memiliki peran penting dalam membesarkan dan mengawasi anaknya bukan saja ibunya. Peran ayah akan memberikan pengaruh terhadap perkembangan ketrampilan sosial, perkembangan kognitif, dan emosional anak sehingga menjadi kurang optimal dalam kehidupannya, sehingga peran seorang ayah bukan saja untuk melengkapi kebutuhan sehari-hari.

Bentuk-bentuk peran ayah terhadap pola pengasuhan anak usia dini:

a. Seorang ayah bertanggung jawab juga terhadap pengembangan kedisiplinan terahadap anak, karena anak usia dini berada pada masa emas anak anak meniru apa yang ia anggap benar. Seorang ayah dapat mendidik anak dengan menggunakan kegiatan bermain yang sederhana saja yang terpenting adanya hubungan interaksi antara ayah dan anaknya. Sehingga anak akan meniru ayahnya memalui interksi yang 
dilakukan karena pada dasarnya kedisiplinan bukan saja berkaitan dengan kekersan, hukuman.

b. Peran seorang ayah pun akan memberikan rasa aman kepada anak nya agar anaknya merasa aman dan nyaman. Seorang ayah akan paham dimana kelebihan dan kekurangan anaknya sehingga ayah anak memberikan perlindungan terhadap anaknya. Seringkali seorang ayah tidak paham dengan anak nya, karena pemahaman yang dimiliki kalau untuk memahami anak itu adalah urusan seorang ibu karena peran seorang ayah hanya mencari nafkah (Vivi, 2018) .

Emosi

Menurut Santrock, (2011) Emosi merupakan perasaan atau hal yang ia rasakan dalam dirinya yang terjadi pada saat melakukan interaksi penting bagi mereka.. Anak mempunyai perkembangan dari ia lahir hingga ia dewasa nantinya semua tahap perkembangan ini pasti akan melewati pengaruh emosional pada anak (Qodariah \& Pebriani, 2016) . Emosi terbagi atas, Terpesona ,Marah, Terkejut, Kecewa, Sakit, Takut, Tegang. Keunggulan seseorang mempunyai emosi:

1. Emosi yang dibentuk akan menghasilkan sebuah komunikasi yang dapat mempengaruhi interaksi. Pada dasarnya ketika melakukan interaksi maka akan menimbulkan emosi. Pada saat melakukan komunikasi dalam kegiatan seharihari dengan orang lain akan mengirimkan pesan.

2. Memotivasi melalui emosi. Karena emosi akan memberikan rekasi bagaimana menghadapi situasi (Safira \& Saputra, 2009).

Emosi memiliki beberapa karakteristik secara umum:

1. Subjektif merupakan sifat dari emosi misalnya pengalaman dan berpikir.

2. Tidak tetap

3. Pancaindra sangat berhubungan karena panindara dapat melihat dan merasakan insiden atau peristiwa

Ciri-ciri emosi anak usia dini:

1. Emosi yang ditimbulkan bersifat sementara atau singkat. 
2. Hebat dan kuat ketika di lihat.

3. Emosi dapat berakhir secara tiba-tiba tidak kekal.

4. Emosi anak dapat diprediksi melalui tingkah laku nya (Jahja, 2011) .

\section{Pembahasan}

Keluarga menjadi pendidikan pertama yang diperoleh anak. Semua pendidikan yang di terima oleh anak bersalah dari keluarga atau orang tua sejak lahir anak mendapat kasih saying yang diberikan oleh orang tuanya kepada anak. Untuk merawat anak bukan hanya pekerjaan seorang ibu saja tetapi peran seorang ayah pun ikut serta dalam merawat dan memberikan pendidikan terhadap anak. Banyak yang beranggapan bahwa tugas seorang ayah hanya mencari nafkah untuk istri dan anak-anak nya akan tetapi semua itu harus diluruskan misalnya ketika seorang istri setelah melahirkan sosok suami tidak berada didekat istri sebab sebagian orang berspekulasi bahwa untuk merawat, menjaga, mendidik anak itu adalah tugas seorang ibu bukan ayah . Pada dasarnya peran seorang ayah dalam mendidik anak sangat mempengaruhi perkembangan anak baik kognitif ataupun emosi anak. Karena peran seorang ayah akan mempengaruhi emosi pada anak ketika seorang ayah memberika perhatian dan kasih saying kepada anaknya. Anak akan merasa senang dan gembira bersama ayah nya. Anak akan merasa senang bermain dengan ayahnya maka emosi yang dikembangkan adalah emosi positif, apabila emosi positif terus dikembangkan dan distimulasi maka kemampuan dalam mengendalikan emosi anak akan baik. Perkembangangan emosi merupakan hal yang terpenting karena didalam perkembangan emosi ini sangat diharapkan untuk mengelola emosi yang baik sehingga apabila emosi baik yang berkembang maka akan berpengaruh terhadap sikap dan menimbulkan perilaku yang positif. (Qodariah \& Pebriani, 2016).

Berbeda dengan seorang ayah yang tidak tahu dengan perannya sebagai ayah misalnya ayah yang memberikan permainan gudget kepada anak nya agar anak nya tidak menggagunya saat berkerja. hal ini menujukkan ayah yang tidak memberikan kasih saying terhadap anaknya karena ia membiarkan masa-masa emas nya terkubur dengan teknologi seperti gudget. Hal ini akan mengakibatkan pengaturan didalam diri anak tidak akan berkembang dan berpengaruh terhadap emosi anak. Seorang ayah harus memberikan waktu yang luang terhadap anaknya sehinga anak akan merasa gembira dan 
senang.Pengaturan diri merupakan sebuah pengendalian terhadap anak dalam berperilaku sehingga melibatkan seluruh aspek perkembangan pada anak baik emosi, kognitif ataupun sosial.(Widiastuti, 2016)

\section{Kesimpulan}

Dalam mendidik anak seorang ayah harus merawat dan menjaga anak ketika didalam kandungan bukan saja ketika anak sudah lahir atau pun dewasa. Anak akan mersa aman dan nyaman berada di dekat ayah apabila ayah memberikan kasih saying yang tulus pada ananya. Sosok seorang ayah sangat mempenggaruhi pertumbuhan dan perkembangan anak usia dini dengan melalui berinteraksi dengan ayahnya sehingga anak mendapat pengalaman yang akan ia contoh. Kedekatan antara seorang ayah dan anak membuat sebuah keharmonisan didalam keluarga sosok ayah dan sosok seorang ibu tidak dapat digantikan oleh siapa pun, masing-masing mereka sudah memiliki peran. Ayah dan anak saling berinteraksi akan mengakibatkan perkembangan emosional yang baik pada anak karena anak dapat merasa senang dan percaya diri yang tinggi. Ketika peran ayah sudah dijalankan dengan baik maka perkembangan kognitif anak akan baik akan mempengaruhi kompetensi sosial pada anaknya sehingga hubungan emosional antara ayah dan anak dapat berkembang dengan baik hal ini akan berdampak positif untuk masa selanjutnya pada anak.

\section{Referensi}

Dagun, S. M. (2002). Psikologi Keluarga (2nd ed.). Jakarta: PT Rineka Cipta.

Djamarah, S. B. (2014). Pola Asuh Orang Tua dan Komunikasi dalam Keluarga. Jakarta: PT rineka cipta.

Hazizah, N. (2018). The Importance of Playing for Developing Intelligence in Early Childhood, 169(Icece 2017), 213-215.

Jahja, Y. (2011). Psikologi Perkembangan. Jakarta: Kencana.

Qodariah, L., \& Pebriani, L. V. (2016). Recognizing Young Children's Expressive Styles of Emotions (2-6 Years Old). Proceedings of the 3Rd International Conference on Early 
Childhood Education (Icece 2016), 58, 254-261.

Safira, T., \& Saputra, N. E. (2009). Manajemen Emosi. Jakarta: PT Bumi Aksara.

Vivi, A. (2018). Fatherhood Dalam Perkembangan dan Pendidikan Islam Anak Usia Dini. Pendidikan Anak Usia Dini, II, 37-48.

Widiastuti, A. A. (2016). Preschoolers Self-Regulation and Their Early School Success. Proceedings of the 3Rd International Conference on Early Childhood Education (Icece 2016), 58, 39-43. 